\title{
Lärares (digitala) kompetens före, under och efter covid-19
}

\author{
Linnea Stenliden, Linköpings universitet \\ Anna Martín Bylund, Linköpings universitet \\ Lena Landkvist, Motala kommun \\ Linda Ekström Lind, Linköpings kommun \\ Susanna Kellgren Lundberg, Linköpings kommun \\ Hannes Stenmark, Motala kommun \\ Cornelia Wilhelmsson, Linköpings kommun
}

\begin{abstract}
This study chrono-logically investigates teachers' professional knowledge in relation to the digitally 'boosted' educational landscape caused by the Covid-19-pandemic. The aim is to describe how teachers employ their competences under extreme digitized circumstances compared to ordinary, to greater extent analogically organized schooling. The study is inspired by action research where five secondary and upper secondary teachers document their work between March 19 and April 2020. Contrastive analysis highlights qualitative aspects of teachers' (digital) competence when teaching is affected by digital "interferences" in its corporeal and material framing, a dissolved spatiality and "truncated" senses/sensuousness. Employing different dimensions of knowledge in terms of intellectus and ratio, the study argues that subjective, emotional and relational processes of teachers' digital competence need to be prioritized in contrast to the easily measurable aspects that tend to overrun the discussions about educational digitalization and its knowledge in society.
\end{abstract}

Nyckelord: covid-19, skolnedstängning, digital kompetens, lärare, ratio, och intellectus

Författarkontakt: Linnea Stenliden, Linköpings universitet, linnea.stenliden@liu.se 


\section{Introduktion}

Under de senaste årtiondena har mängder av digital utrustning förts in i skolans värld med förhoppningar om att förändra och effektivisera undervisningen för att detta i förlängningen ska leda till förbättrade resultat (Utbildningsutskottet, 2015). Detta införande av digitala medier i utbildning kan beskrivas som en trojansk häst utifrån vilken reformer kan spira, väl innanför det traditionella (konservativa) skol-etablissemangets väggar (Player-Koro, Bergviken Rensfeldt \& Selwyn, 2018). Det finns dock vittnesmål om att dessa reformer till viss del uteblivit eller saknat önskad verkningskraft (Selwyn, Nemorin \& Bulfin, et, al. 2017; Jankhe \& Hirsh, 2020). Få resultat har kunnat kopplas till skolans digitalisering (Fransson, Holmberg \& Lindberg et, al., 2019). Våren 2020 har istället en annan sorts trojanska hästar i form av virus-krönta mänskliga kroppar orsakat en historiskt sett unik omställning av utbildningspraktiker både i Sverige och internationellt. När gymnasieskolan får besked om att gå i distansläge och grundskolan skall förbereda sig på eventuell distansundervisning i mitten av mars 2020, blir detta en katalysator för lärares och elevers användning av digital teknik. Eftersom lärares kunnande och handlande aktualiseras på ett exceptionellt sätt av denna omställning, finns potential att synliggöra det mest grundläggande, i detta fall avseende lärares kompetens vid digital undervisning.

Bergdahl \& Nouri (2020) visar på mängden av digitala lösningar som sätts i bruk i skolan, liksom hur tillgången till teknik och tekniska förutsättningar i hemmen skapar nya undervisningsvillkor och pedagogiska strategier under covid-19 pandemin. Ett nytt digitalt undervisningslandskap uppstår där olika tekniska lösningar och olika digitala resurser påverkar och förändrar undervisningens natur vilket i sin tur ställer krav på lärare och elevers kompetenser att agera och navigera i denna terräng. Samtidigt presenterar abnormiteten i landskapet också möjligheter att upptäcka sådant som är en del av lärares yrkeskunnande och som kanske alltid gjorts, men som tidigare, på grund av de mer normala i omständigheternas natur, varit svårare att urskilja (Jahnke, 2020), inte minst i relation till det som i vardagligt tal åtminstone tidigare benämnts som skolans "digitalisering”. Genom att synliggöra hur detta kan ta sig uttryck i mer "vanliga" undervisningssituationer och i de digitala undervisningssituationer som uppstår där lärare, elever och teknik ska samspela i samband med “omställningen" kan en fördjupad förståelse för vad denna "digitalisering” kan tänkas handla om i praktiken och vari lärares (digitala) kompetens kan bestå. 
I den här studien utforskar vi utifrån en kronologisk logik olika aspekter av (oformulerad) yrkeskunskap i det digitalt "boostade" undervisningslandskap som covid-19-pandemin orsakar. Kunskaper sprungna ur omställningen av skolan behöver förmedlas till ett "efteråt". Vad hände? Vad fungerade? Vad blev viktigt? Det kommer att finnas en önskan om aspekter som 'hur snabbt' bredband behövdes? hur många digitala verktyg togs i bruk? hur påverkades elevers måluppfyllelse? Men också kvalitativa aspekter från omställningen av undervisningen kommer att efterfrågas. Frågor kommer aktualiseras angående lärares förmåga till adaptivitet och flexibilitet liksom frågor angående centrala aspekter av lärares yrkeskunnande i relation till organisation av digital (distans/online) undervisningen. Denna studie avgränsar sig och fokuserar på dessa kvalitativa aspekter.

Syftet är att skapa kunskap om hur olika lärarkompetenser gestaltar sig i undervisning under extremt digitaliserade omständigheter jämfört med mer vanlig och i långt högre grad analogt organiserad skolverksamhet. Syftet är också att utifrån detta diskutera hur denna kunskap kan integreras $\mathrm{i}$ ett fortsatt arbete med att utveckla digital undervisning och lärares digitala kompetens när vi efter covid-19 skapar en ny normalitet.

\section{Tidigare forskning}

Det finns ännu ett begränsat antal studier som rör pedagogiska effekter av tidigare skolomställningar på grund av pandemiska orsaker och ännu färre studier som fokuserar dessa aspekter i relation till covid-19-pandemin. Däremot finns det mängder av studier i relation till lärande genom digital undervisning, distansundervisning och onlineundervisning. Onlinelärande har sitt ursprung i vad som traditionellt varit känt som distansutbildning och som definierats som "den praktiska delmängden av en utbildning som hanterar avstånd i undervisning där tid och rum är kritiska attribut; det vill säga elever och lärare separeras med geografiskt avstånd och / eller tid” (Yacci, 2000, s. 1). Numer genomförs distansutbildning antingen genom en blandning av fysisk- och distansundervisning eller helt online där all undervisning och allt undervisningsmaterial tillgängliggörs för elever/studenter digitalt (Tabor, 2007). Undervisning kan genomföras både synkront och asynkront i tid (Anderson \& Dron, 2011).

I en inzoomning mot studier angående onlineundervisning i relation till skolnedstängningar, i syfte att minska smittspridningen vid pandemier, visar Fox $(2003 ; 2007)$ som studerat SARS- 
utbrottet i HongKong, där skolor stängdes ned under en period 2003, att fyra faktorer är särskilt avgörande för lärarna i relation till att skapa en fungerande omställning till undervisning på distans. Det handlar om tillgång till digitala teknologier och teknisk support på plats, kunskap om undervisningsstrategier för att maximera elevernas deltagande, samt att elever/studenter introduceras till distansundervisning innan de lämnat skolan. Bergdahl och Nouri (2020) visar i en svensk studie att strukturella frågor hamnat i fokus under den tidiga processen att omforma undervisningen till distansundervisning vid covid-19-pandemin. Lärare och skolledare funderar mycket kring tekniska hjälpmedel såsom plattformar, tillgång till digitala läromedel och kommunikationsverktyg liksom elevernas tillgång till datorer, pekplattor och tillräcklig internetuppkoppling. Likaså aktualiseras frågan om övergripande strukturer gällande förhållningssätt till GDPR, it-policys och upphandlingar. Studien visar att det är viktigt att de tekniska förutsättningarna fungerar på en övergripande nivå och att elever har kunskap om, och tillgång till, datorer och internetuppkoppling samt att applikationer finns tillgängliga. Det är också viktigt att undervisningen på distans kan varieras. Basilaia och Kvavadze (2020) beskriver i en annan färsk studie hur Georgien, som ett av 188 länder i världen, drabbas av en skolnedstängning på grund av covid-19. Här behöver lärarna anpassa de ursprungliga skoluppgifterna efter den nya situationen och de är tvungna att utveckla nya arbetssätt. I ytterligare en studie påvisar Zhou, Li, Wu och Zhou (2020) liknande resultat i samband med covid-19-pandemin när i online-utbildningen "School's Out, But Class's On” införs för 270 miljoner elever i Kina. Studien visar att lärare tenderar att kopiera den klassiska klassrumsundervisningen. Detta menar Zhou, et al, (2020) påverkar mötet med eleverna som kan kräva andra förmågor av lärarna. Zhou, et al, (2020) visar dock att lärarens roll efterhand utvecklas från att vara kunskapsförmedlare till handledare. Eleverna, som behöver arbeta mer självständigt i onlineundervisningen, utvecklar därmed också nya färdigheter. En annan aspekt som både Basilaia och Kvavadze (2020) liksom Zhou et al. (2020) visar är att det mer självständiga arbetet för eleverna leder till ett ökat inflytande över lärandet. Samtidigt innebär distansundervisningen också att elevernas individuella behov är svårare att upptäcka och att individuell vägledning ofta uteblir. Båda menar att de lågpresterande eleverna drabbas mest av detta. Zhou et al. (2020) pekar avslutningsvis på att ett framtida arbete behövs för att utveckla pedagogik som bidrar till att stärka mötet med elever i onlineundervisning.

De flesta av dessa resultat finns också i forskning angående onlineundervisning generellt, oavsett skolstängningar. Den pekar också ofta på elevers upplevelse av onlineundervisning i termer av isolering, frånkoppling från kamrater och lärare, liksom hur förberedelser för att 
delta i och att lära sig bli undervisad i en online-miljö är viktiga faktorer att ta hänsyn till (Gunawardena, 1995; 1997; Russo \& Benson, 2005; Sazmand Asfaranjan, Shirzad, Baradari, et al., 2013 med flera). Ofta visar sig dessa faktorer konstruera en uppfattning att onlineundervisning är en pedagogisk underlägsen form av undervisning (Liu, Gomez, \& Yen, 2009). Gorsky \& Blau, (2007) beskriver dock att det som utmärker online-lärare är deras strävan mot att skapa en hög standard i sin undervisning. Sawyer (2004) pekar på att det i den tidiga onlineundervsingen fanns diskrepans mellan lärares digitala undervisning att vissa lärare tenderade att arbeta utifrån "manus" ("scripted teacher-proof curricula") medan andra lärare snarare gick i riktning mot ett improvisationsliknande förhållningssätt. De senare försöker förhålla sig improvisatoriskt i det pedagogiska mötet med eleverna för att bjuda in till interaktion, vilket kan liknas vid en jazzmusikers förmåga att förhålla sig fritt till en förutbestämd ackordföljd.

Flera studier pekade tidigt på (se till exempel Rourke et al, 2001; Tu, C., \& McIssac, 2002) att den sociala närvaron i online undervisning behöver utvecklas då den visat sig vara viktig för lärare och elever. Olika känslosymboler, personliga historier och humor beskrivs kunna förstärka känslan av denna närvaro. Främst lyfter denna forskning fram teknikens begränsningar snarare än att fråga vad det betyder att vara närvarande online (Haj-Bolouri \& Flensburg, 2017). Det har nämligen visat sig vara svårdefinierbart. De flesta definitioner som görs beskriver social närvaro som förmågan att uppfatta andra i en online-miljö (Annand, 2011; Kreijns, Van Acker, Vermeulen, \& Van Buuren, 2014; Lowenthal, 2010; Oztok \& Brett, 2011). Shé et al (2019) visar i en senare forskningsöversikt att social närvaro i onlineundervisning handlar om att åstadkomma relationella band där lärares personliga kontakt med enskilda elever är avgörande. Dessa bygger på ögonkontakt, leenden, upplevd vänlighet samt att lärare visar sig villiga att hjälpa eleverna i arbetet (Nilsson, 2012), vilket kan ske genom snabb bekräftelse och återkoppling (Gorsky \& Blau, 2007). Viktigt att påpeka är att elevers upplevda förhållande till läraren har betydelse för elevers engagemang i all undervisningen (Ågård, 2014), men det är särskilt viktigt i onlineunder- visning. So \& Brush (2008) visar att elever uppfattar sitt lärande i sådan undervisning med större tillfredsställelse om lärarens sociala närvaro upplevs som god och att nästan allt som lärare gör tolkas relationellt av eleverna. De pekar också på paradoxen att lärare ofta riskerar att finna sig själva i envägskommunikation i distansundervisnings-situationer, vilket i sig kan motverka upplevelsen av social närvaro både för elever och lärare. Detta kan relateras till vad HajBolouri \& Flensburg (2017) problematiserar när de försöker beskriva essensen av närvaro i 
online-undervisning något annorlunda. Med hjälp av begreppet digital dasein menar de att närvaro online handlar om att vara här, att vara där och vara var som helst/överallt både digitalt och fysiskt, men också asynkront och synkront. Sammantaget kan slutsatsen dras utifrån denna forskningsöversikt att onlineundervisning ställer höga krav på lärares (digitala) kompetenser. Frågan kvarstår, särskilt i relation till begreppet digital dasein, vilken kunskap lärare behöver för att klara av att navigera i en sådan överskridande kontext?

\section{Teoretiska utgångspunkter}

I våra anspråk på att kunna säga något om lärares (digitala) kompetens “före, under och efter" covid-19, ansluter vi oss till tid som ett kronologiskt fenomen, där vi lär av våra erfarenheter, rör oss i ett pågående och utvecklas medan tiden går framåt. Samtidigt menar vi att lärares (digitala) kompetens måste problematiseras med hjälp av två olika dimensioner av kunskap ratio och intellectus. Dessa begrepp kan genom att de är sprungna ur ett historiskt "före" belysa hur inte bara skolan utan hela det $n u$-tida samhället blivit upptaget (fixerat) av systematisering och mätbarhet (Bornemark, 2018). Vi menar att lärares (digitala) kompetens kan beskrivas som en uppsättning urskiljbara och därmed också mät- och manualiseringsbara kunskaper, exempel på sådana kunskaper kan vara förmågan att välja, hantera, och viljan att applicera, olika digitala verktyg i sin undervisning. Med hjälp av Schön $(1983,1987)$ skulle den typen av kompetens kunna beskrivas som teknisk rationalitet, där läraren - experten tillämpar regler och teori när dessa appliceras i praktiken. Den typen av kunskap finns före själva handlingen och kan därför också beskrivas som en manualisering av egna och andras erfarenheter. Å andra sidan, kan lärares (digitala) kompetens, utifrån intellektus, också beskrivas som ett reflexivt handlande i situationer som är oförutsägbara och osäkra, likt de digitala undervisningssituationer som lyfts fram ovan. Schöns (1983) begrepp reflektion-ihandling beskriver vetandet som sammanväxt med handlandet och oskiljbart från känslorna i en så kallad "reflektiv konversation med situationen" (1983:268). Reflektionen är alltid ett svar på en störning och ett försök att lösa ett i situationen uppkommet problem. Av reflektionen följer en anpassning, en justering. Schön (1983) menar att kunnande aldrig kan definieras i förväg. Den erfarenhetsbaserade kunskapen som fungerar "friktionsfritt", utan störningar, kallar han därför istället för kunnande-i-handling.

Vi poängterar att de två olika beskrivningarna av lärares (digitala) kompetens här inte är varandras motsatser utan två olika dimensioner av en komplex kunskap (ratio och intellektus) 
som båda har sitt unika värde. Med fokus på digital kompetens, som en teknisk rationalitet, skulle vi relativt enkelt, kronologiskt, kunna konstatera vilka olika digitala lösningar som satts i bruk under våren 2020, liksom utvärdera deras effektivitet. För en mer komplex och komplett bild av lärares (digitala) kompetens eller kunnande riktar vi i denna studie också blicken mot detaljerna i de situationer där de tekniska lösningarna satts i bruk, och de krav som situationerna ställer på lärare att reflektera i handling, anpassa och justera sina handlingar utifrån störningar i pågående undervisning. Detta bottnar i en förståelse för lärares arbete som ett responsivt fenomen skapat i situationsbundna relationer. För att undersöka undervisning och förstå hur de digitala omständigheterna våren 2020 "stört" lärare och utmanat dem i sitt arbete är studien inspirerad av aktionsforskning där vi använder oss av kontrastiv analys av lärares reflektion- och kunnande-i-handling.

\section{Metod}

Studien genomförs inom ramen för det nationella projektet "Utbildning, lärande och undervisning” (ULF), vilket är en försöksverksamhet under perioden 2017-2021 angående praktiknära forskning. Det studieobjekt som ursprungligen formulerades kopplat till ULFprojekt handlade om högstadie- och gymnasielärares digitala kompetens med fokus på svenskämnet. I samband med omställningen av svensk skola som blev följden av covid-19pandemin omformulerades studieobjektet till att fokusera lärares (digitala) arbete under dessa specifika förhållanden som tidsmässigt kopplas till tiden från uppdagandet av de första covid19-fallen i Sverige, där t ex en av lärarna i projektgruppen är en av de som testas initialt och får ett positivt provsvar fredagen den 13 mars, där skolverksamheter från gymnasieskolan och uppåt rekommenderas att stänga från och med onsdagen den 18 mars och en ny lagen träder i kraft som gör det möjligt att stänga även förskolor och grundskolor några dagar senare, den 21 mars. Materialet som ligger till grund för denna studie skapades i närtid till dessa händelser, närmare bestämt mellan den 19 mars och 2 april 2020.

\section{Deltagare}

I studien ingår fem lärare i studien från två olika svenska kommuner samt två forskare. De fem lärarna har mellan 2 och 20 års erfarenhet. Samtliga lärare undervisar under studiens gång i svenskämnet varav tre på grundskolan och två på gymnasiet. De båda forskarna arbetar på samma universitet, inom området utbildningsvetenskap, pedagogiskt arbete. 


\section{Aktionsforskningsinspirerad studie}

Den metod som använts i studien är inspirerad av aktionsforskningsstudier. Aktionsforskning är samlingsnamnet för en palett av olika forskningsansatser vilka alla innefattar en relation mellan handlandet i och tänkandet om praktiken (Lincoln, 2001). Grundläggande för de olika ansatserna handlar om kombinationen av två involverade parter, nämligen forskare och praktiker där gränsen mellan dessa kan vara diffus (Reason \& Bradbury, 2001). Andra centrala moment handlar om; att ställa frågor till praktiken, att iscensätta en aktion (en planerad handling för en tänkt förändring), att följa processen systematiskt samt reflektera över vad som sker (Touboulic \& Walker, 2015). I denna studie omsätts dessa moment mer eller mindre och den kan därför inte beskrivas som en klassisk aktionsforskningsstudie. Framför allt skiljer sig studien angående "att iscensätta en aktion”. Den aktion som fokuseras här är inte iscensatt av praktiker och utgår inte ifrån något fördefinierat behov som identifierats i skolan. Istället kan de trojanska hästarna i form av covid-19 ses som iscensättare av det händelseförlopp i skolans praktik som här studeras. Däremot överensstämmer övriga punkter väl med att en grupp människor, här lärare tillsammans med forskare, formulerar och genomför forskningsprojektet, med gemensamt ansvar för forskningsprocessen, vilket innebär att deltagarna arbetar tillsammans i ett lärarforskarteam med alla studiens olika moment.

Arbetet cirkulerar kring fyra centrala delar, de konkreta utbilningserfarenheter som studeras, de reflekterande observationer som genomförs, den abstraktion och konceptualisering som realiseras och det aktiva experimenterande som uppstår angående analys, validering och återkoppling till den konkreta utbildningspraktiken. Detta kan också beskrivas som att studien tar utgångspunkt i den praktiska skolvardagen genom egenreflektion i det som inom aktionsforskning benämns som "första person" där undersökandet av våra dagliga handlingar är, sedda inifrån (Reason \& Bradbury 2001). De individuella reflektionerna kan föras samman till reflektion i grupp i så kallad “andra person” (Reason \& Bradbury 2001). Det innebär ett gemensamt undersökande av studieobjektet och skapande av olika typer av underlag och bearbetade transkriptioner. Dessa kan i sin tur analyseras och kunskaper som utvecklas kan vidare kommuniceras på organisationsnivå i “tredje person” (Reason \& Bradbury 2001).

\section{Etiska överväganden}

Den etiska aspekten är central när man arbetar med utgångspunkt i aktionsforskning. Det är alltid inom en organisation (skola) svårt att isolera saker som händer, på något sätt kommer de 
förmodligen påverka människor utanför den direkta forskningen. Som forskare och forskande lärare behöver man ur ett etiskt perspektiv vara beredd på hur man ska hantera en sådan eventuell situation (Denscombe, 2014). I denna studie informerades inte bara de forskande deltagande lärarna om studiens syfte och förväntade publikationsformer utan de var också med att formulera detta, liksom att fatta beslut om arbetsprocess och publicering. Dessutom informerades alla om att deltagande var helt frivilligt och kunde när som helst avbrytas. Lärarna gav i samband med detta ett muntligt samtycke till att delta i och genomföra studien. Alla namn har anonymiserats i studien och de forskande lärarna har också getts möjligheter att kommentera och göra eventuella klargöranden innan publicering.

\section{Genomförande}

Att dokumentera egna konkreta utbildningserfarenheter, "hur kan jag skriva om det jag ser?", innebär att konfrontera inte bara vad det är "att se" utan också "att tänka och reflektera". Detta uppmanar därför till överväganden när det gäller jaget i dokumentations- och analysarbetet: det seende jaget och det skrivande jaget (Devereux, 1967). Genomförande av studiens dataproduktion och analys innebär att (1) dataproduktion har genomförts i första person (2) analysarbetet har skett i växelverkan mellan första och andra person.

\section{Dataproduktion - i första person}

För att dokumentera erfarenheter och händelser i skolan valdes skriftlig och visuell dataproduktion. Det innebar att lärarna dokumenterade vad de såg och upplevde med hjälp av dagboksanteckningar, fotografier, skärmdumpar och noteringar. Fokus låg på de konkreta utbildningssituationer och erfarenheter som uppstod vid tidpunkten för det förändrade utbildningslandskapet som granskas i denna studie. Det innebär ett fokus på vardagliga händelser som är gemensamma oavsett skolform. De är sedda med ett inifrånperspektiv och det är lärarnas dokumentation av sina personliga erfarenheter som utgör det empiriska materialet i studien.

\section{Analysarbete, steg 1 - $i$ andra person}

En abstraktion och konceptualisering av det empiriska materialet kom till stånd genom en process i flera steg. En barock analysmetod har använts vilket innebär ett försök att öppna upp för en analytisk känslighet utanför bestämda skalor, kategorier och tidsbegrepp (MacLure 2013). Det betyder att stabila hierarkier av subjekt och objekt, formellt och informellt, det specifika och allmänna, i analysarbetet kan föras in i en produktiv oordning och osäkerhet. På 
detta sätt kan olika fragment som framkommer ur dagböckerna, från fotona och anteckningarna öppnas upp, i ett försök att kunna se bortom det redan kända och på så sätt kunna analysera den komplexitet som uppstår av alla de interaktioner som utgör undervisningen.

För att skapa ett gemensamt sammanhang för undersökande av studieobjektet har reflekterande observationer genomförts av lärarforskarteamet. Det innebar att varje lärare presenterade sin dokumentation av de personliga undervisningserfarenheterna samtidigt som samtliga deltagare i teamet gjorde egna noteringar angående det som kunde uppfattas som "glödande" i materialet. Glödande är en term som används av MacLure (2013) för att beskriva de ögonblick av intensitet som fångar vår uppmärksamhet av någon anledning. MacLure (2013) förklarar att det handlar om att vara uppmärksam mot det som överraskar, att notera det som skapar en tanke, en undran snarare än om ett kartläggande av tydliga, definitiva kategorier. I en fördjupad analysdiskussion (i andra person) framkom en mängd infallsvinklar, ostrukturerade synpunkter och relativt trassliga upplevelser. Dessa framväxande muntliga kluster bearbetades sedan vidare till skriftliga “empiriska händelsebeskrivningar".

\section{Analysarbete, steg 2 - växelverkan mellan första och andra person}

Att omvandla klustren betyder att lärarna individuellt utvecklade, detaljerade, komplexa, skriftliga beskrivningar av klustren. Det vill säga, det som lärarna tidigare själva observerat och dokumenterat på olika sätt, sedan redovisat och därefter diskuterat i lärarforskarteamet. Jones, Holmes, Macrae, \& Maclure (2013) menar att när försök görs att redovisa händelser i ett klassrum handlar det om att försiktigt röra sig mot mångsidiga beskrivningar eller lekfulla “förvirringar" så att det bekanta i klassrum framstår i den komplexitet dessa rum utgörs av. De “empiriska händelsebeskrivningar" som skapades har analyserats i växelverkan mellan första person (individuella reflektioner) och i andra person (genom dialog i lärarforskartemet). Detta har inneburit att en kontinuerlig avstämning av begrepp och helheter i analysen möjliggjorts. I presentationen av studiens resultat används excerpt ur dessa händelsebeskrivningar för att tydliggöra och förankra analysen. I analysen fokuseras generella aktiviteter i lärares arbete som är så alldagliga och rutiniserade att de många gånger går obemärkt förbi. Exempel på sådana aktiviteter är att sätta igång en lektion och ta närvaro/frånvaro, att svara på frågor, att följa upp elevernas arbetsprocess etcetera. För att tydliggöra dessa aktiviteter kontrasterar vi lärares arbete på en gymnasieskola årskurs 1, som 
nyligen gått in i distansläge, med en lärares arbete på en högstadieskola, årskurs 8 som fortsatt bedriver undervisning i ett vanligt, fysiskt klassrum i skolan.

\section{Resultat}

I resultatavsnittet utgår vi från två beskrivningar som två olika lärare i svenskämnet har gjort i relation till sin litteraturundervisning. Den ena läraren - Nina - beskriver sitt arbete i ett digitalt undervisningsrum i svenska 1, årskurs 1. Den andra läraren - Liselott - beskriver sin undervisning i svenska för årskurs 8, i ett vanligt, fysiskt klassrum i skolan.

Genom att kontrastera de olika beskrivningarna kan vi få fatt i vad som framstår som en "störning” i det mer ovana och osäkra digitala undervisningsrummet. Vi undersöker hur läraren i beskrivningarna genom reflektion-i-handling reagerar på och eventuellt justerar sitt kunnande-i-handling i samspel med denna störning.

\section{Att verka i upplöst spatialitet med förändrade sinnliga/kommunikativa förutsättningar}

Det första exemplet fokuserar på uppstartandet av en lektion. I excerpt 1a berättar gymnasieläraren Nina hur denna aktivitet blir till i en svensklektion i det nyligen iscensatta distansläget. I excerpt $1 \mathrm{~b}$ beskriver högstadieläraren Liselott hur en liknande lektion börjar i ett "vanligt", fysiskt klassrum.

\footnotetext{
1a. Lektionen startar och eleverna är inbjuda i Meet. En efter en ansluter. Några har sin kamera på, de flesta inte. Några har mikrofonen på, de flesta inte. Jag räknar elever. 27 nu. Undrar om några är sjuka? Ställer en fråga: “Någon som känner till att någon är sjuk?” Tystnad. Sedan slår en plikttrogen elev på mikrofonen och säger: "Nä, inte jag i alla fall”. Det plingar till: “Ursäkta att jag är sen. Jag trodde inbjudan var i mejlen!” Nu är vi 28 och lektionen startade för tre minuter sedan. Jag tänker att jag får se om någon är sjukanmäld senare. Jag börjar: "Hej, allihopa! Kul att ni är här! Mår ni bra?” Precis när jag ställt frågan inser jag att den är lite dum, eftersom alla inte kan svara samtidigt.

1b. Jag låser upp och släpper in eleverna. En av dem meddelar att han är "så jävla trött” och troligen kommer att somna i simhallen, när de ska dit efter min lektion. Jag svarar att det inte är någon bra idé, och så kommer lektionen igång. Efter att jag förklarat att de får använda lektionen till att läsa och jobba med läxuppgifterna, så att de är förberedda inför sitt bokcirkelmöte som de ska ha i sina olika grupper dagen efter, sätter de flesta igång. Eleven som glömt sin bok får låna en, en annan elev har glömt sin dator och får låna en penna. De kommer också igång.
}

Det finns förstås flera likheter mellan de olika situationerna och hur uppstartandet av en lektion kan gestalta sig. Att någon elev är sen eller att någon glömt en bok är vardagliga 
händelser som ofta ingår i en beskrivning av en lektionsstart. Samtidigt framträder några väsentliga skillnader när de båda situationerna kontrasteras. "Störningen" i den digitaliserade undervisningssituationen kan beskrivas i termer av en upplevd annorlunda spatio-temporalitet, där en gemensam fysisk infrastruktur (väggar, dörrar) och förnimbara och förnimmande elevkroppar saknas. Detta skapar i sin tur ett något begränsat eller "stympat" sinnligt handlingsutrymme.

Nina beskriver att hennes lektion "startar" på utsatt tid vilket motsvarar att det schemalagda digitala mötet tickar igång på exakt starttid. Detta kan liknas vid Liselotts öppnande av klassrumsdörren i excerpt 1b. När eleverna "släpps in" med sina kroppar i det fysiska klassrummet "ansluter" de en efter en i det digitala rummet. Anslutningen innebär dock inte per automatik att eleverna blir synliga eller hörbara för Nina i den digitala undervisningssituationen, på samma sätt som de blir för Liselott när de samlas i hennes analoga klassrum. Nina räknar hur många elever som är "på plats" men kan inte direkt skapa sig en snabb överblick över vilka som är där eller inte, då de flesta eleverna inte har sina kameror eller mikrofoner på. Att någon ansluter åtföljs av ett pling, men huruvida Nina kan avgöra vem det är, blir avhängigt elevens beslut att slå på kamera och/eller ansuta mikrofon och välja att aktivt säga något, t ex be om ursäkt för sen ankomst.

Att Liselott inte på samma sätt beskriver tankegångar kring frånvaro och närvaro i början av sin lektion kan ha att göra med att hon har en bättre överblick och kan använda alla sinnesintryck för att snabbt scanna av vem som befinner sig i klassrummet. Dessa sinnesintryck skapar också förutsättningar för att minnas detta i ett senare skede. Liselott kan samtidigt som hon med blicken snabbt läser av det fysiska undervisningsrummet och de närvarande kropparna också ägna sig åt lite småprat kring trötthet med någon elev i samband med att lektionen startar. Liselott uttrycker i samband med detta hur lektionen "kommer igång" och att eleverna "sätter igång”. Det verkar härmed finnas en inarbetad rutin som upprätthålls av de fysiska klassrumsväggarna liksom av ett samspel mellan kroppar som både ser, hör, rör sig i och på andra sätt förnimmer ett gemensamt sammanhang. Igångsättningen av lektionen framstår här som självklar, då den kommer igång av sig själv.

Ett liknande utrymme för att flera saker kan göras samtidigt finns inte i den digitala undervisningssiutation där Nina beskriver att hon aktivt "börjar" med en hälsning riktad till alla som - eventuellt - är på plats. De spatiala gränserna påverkar vad och hur mycket som blir 
möjligt att förnimma, uttrycka och kommunicera inom ramen för samma tidsspann. Denna upplevda mer begränsade samtidighet kommer också fram genom Ninas reflektion kring att “alla inte kan svara samtidigt”. Förvisso kan inte alla prata samtidigt $\mathrm{i}$ ett vanligt klassrum heller men där har deltagarna helt andra möjligheter att läsa av varandras kroppar (uppmärksamma blickar), olika kommunikativa uttryck (nickningar, ansiktsuttryck) och initiativ till att ta ordet (handuppräckning, viskningar mm) jämfört med när alla befinner sig i olika fysiska, om än genom tekniken sammankopplade rum. I det senare fallet blir kommunikationen i högre utsträckning bunden till det verbala uttrycket och ordet måste hela tiden fördelas.

Genom refektion-i-handling svarar Nina på den uppkomna "störningen" och vi tolkar hennes beskrivning av sina handlingar som uttryck för justeringar. Vid avsaknad av en fysisk, rumslig inramning orienterar sig läraren mot andra strukturerande resurser - såsom exakta klockslag på skärmen framför henne, antalet anslutningar och möjliga sjukanmälningar och tid räknad i minuter. På det mer begränsade sinnliga handlingsutrymmet som uppstår, svarar hon med att använda sin röst och verbala uttryck, för att exempelvis sätta igång lektionen.

Exemplet belyser hur det ovana i den uppkomna situationen aktualiserar ett handlande som inte är frånkopplat från tidigare erfarenheter men som med utgångspunkt i dessa prövar mindre beprövade och mer osäkra sätt att agera. Snarare än en slutsats kring att etablerade, invanda handlingsmönster och strukturer per definition skulle vara "bättre", menar vi att kontrasteringen av de två olika situationerna kan styra blicken mot hur ett digitaliserat kunnande-i-handling utkräver just aktiv reflektion och justeringar, både i stunden och på längre sikt.

\section{Att verka utan rummets tidsmässiga gränser och tillfälligheter}

I excerpt 2a berättar Nina om hur hennes arbete med planering av tid och rum kan se ut inför distansundervisning. Detta kontrasteras mot Liselotts beskrivning av en liknande situation som utspelar sig strax innan en lektion börjar (excerpt 2b), liksom ytterligare en beskrivning av hennes lektion när den redan är igång i (excerpt 2c).

\footnotetext{
2a. Det är svårt att beräkna tiden det kommer ta för varje lektion och planeringen måste hålla rakt igenom.

Uppgifterna får inte vara för stora för en lektion, men heller inte för små. Allt måste vara tydligt och lätt att förstå.

[...] Jag skapar arbetsgrupper med cirka fem elever i varje. De ska läsa novellerna och sedan diskutera i grupper samt

dokumentera i delade dokument vad de kommer fram till. Jag schemalägger de delade dokumenten, och novellerna
} 
med uppgifter i Classroom inför varje lektion. Till varje grupp måste jag även skapa diskussionsforum i

Hangout/Meet där de kan samtala. Det tar sin tid. Eftersom jag gör detta innan arbetet startat vet inte eleverna om

vad vi ska göra, men de hinner få inbjudan via mejl, och genast kommer frågor kring vad det är för möte de är

inbjudna till. Jag får svara dem att de får veta senare, men det tar tid att svara alla. [...] Mycket av det som jag i

vanliga fall gör under lektionstid måste nu göras innan lektionen samt även efter lektionen. Under själva lektionerna

ägnar jag mig i hög grad åt att kommunicera med eleverna genom olika forum.

2b. Det är onsdag och klockan är tjugo över tolv. Svensklektionen med 8C ska börja om fem minuter och jag håller på att plocka ihop de saker jag ska ha med mig till salen, när det knackar på dörren. Jag öppnar och möts av en elev i klassen som frågar vad vi ska göra på lektionen idag. Kväver impulsen att meddela att hon får veta det om fyra minuter när lektionen börjar, och säger istället att vi ska fortsätta jobba med bokcirkeln, varpå eleven svarar att hon glömt boken hemma. Jag säger att det finns extraböcker i klassrummet och att det löser sig.

\footnotetext{
2c. En elev passar på när jag går förbi och frågar tyst om det är okej att han går iväg till Stillheten (ett rum som vissa elever som behöver har nyckel till). Det är visserligen lugnt i klassrummet, men jag vet att han lider av ångest låter honom gå iväg. Jag tänker att jag ska titta till honom om en stund. En annan elev, som har det jobbigt med läsningen, säger frustrerat att han inte kan logga in på Legimus och att han inte kommer ihåg texten när han läser. [...]Elevens kompis erbjuder sig att läsa högt tillsammans med honom i ett annat rum. På min fråga om han själv hinner läsa då, svarar han att han kan läsa hemma. Vi går ut ur klassrummet för att hitta någonstans där de kan sitta och jag säger till den första eleven: "schysst kompis du har!” och han svarar: ”ja, jag vet”. "Var rädd om honom”, säger jag, och eleven nickar och ler lite. Jag släpper in dem i ett annat rum och återvänder till klassrummet.
}

Båda lärarna uppvisar i sina beskrivningar en yrkesmässig responsivitet/relationskunskap i det att de är lyhörda för och söker bemöta sina elevers olika uttryck för osäkerhet och olika behov. I båda exemplen blir det också tydligt hur denna relationskunskap, förutom lärare och elever, också inbegriper de materiella omständigheter som utgör undervisningens kontext. Det blir tydligt hur dessa materiella - både digitala och analoga - omständigheter påverkar lärarnas förutsättningar att utöva denna kunskap, liksom formar deras handlingar på olika sätt. "Störningen" i den digitala situationen är liksom i det tidigare exemplet rumsligt betingad.

Exemplen belyser hur planering av digital distansundervisning ställer högre krav på exakthet och detaljerad tidsmässig precision då läraren dels måste skapa själva rummet/rummen och dels måste förhålla sig till ett långt mer begränsat utrymme för spontana anpassningar och ett flexibelt agerande i stunden. För det senare verkar det i den vanliga fysiska infrastruktur som skolbyggnaden utgör finnas ett stort utrymme. Liselott kan svara sin elev direkt, även på följdfrågor och dessutom med ett enkelt "det löser sig" stilla elevens eventuella oro över att ha "glömt boken hemma". Hon kan också spontant och bokstavligen i förbifarten, när hon genom sin fysiska förflyttning i klassrummet kommer nära en elev, bemöta elevens fråga och upplevda behov av att få gå iväg till ett avskilt grupprum, "Stillheten". Nina, som måste planera och dela in sina elever i digitala grupprum i förväg, har inte samma möjlighet att 
kunna vare sig förnimma, ta hänsyn till eller för den delen utnyttja olika tillfälligheter -såsom enskilda elevers specifika behov och andras infall att hjälpa till - i den situationsbundna kontexten när lektionen väl är igång.

Den skriftliga kommunikationen som distansläget genererar kan vara informativ men är just distanserad i både tid och rum. Frågorna om lektionsinnehållet som både Liselott och Lina får innan lektionen startar kan tolkas som uttryck för elevers kontaktsökande. I Ninas fall är eleverna i mångt och mycket bortkopplade från skolans kontext när lektionerna inte pågår och behovet att skapa kontakt är kanske därför mer utbrett. Distansläget är en ny situation också för dem. Både Nina och Liselott tänker i relation till de frågor de får att eleverna/eleven "får veta senare", dvs när lektionen är igång och innehållet/instruktionen kan förmedlas till alla elever på samma gång. Samtidigt, när frågan är ställd, förväntas ett svar. Det är dock stor skillnad i tidsåtgång på att svara en elev muntligt och att svara många i skrift.

I vår mening är den responsivitet som båda lärarna ger uttryck för en central del av en generell yrkeskompetens som också kan beskrivas som ett kunnande-i-handlande. I den digitala infrastrukturen där Nina arbetar störs de vanliga strukturerna för hur lärares kunnande-ihandlande kan utövas vilket genererar reflektion-i-handling och justeringar av responsivitetens uttryck. När allt måste vara planerat och klart i minsta detalj innan lektionen startar och elevernas känsla av sammanhang behöver underhållas utan en gemensam fysisk kontext, skapas en skärm- och tangentbordsrelaterad strukturerande och inkännande praktik, liksom en extensiv och i hög grad skriftspråkligt medierad kommunikation. Denna praktik expanderar på ett sätt som saknar jämförelse i eller utanför det fysiska klassrummet. Expansionen begränsas inte av fysiska rum vilket i sin tur verkar möjliggöra en annan utbredning i tid. Eftersom schemat och arbetstiden ser ut som vanligt, kan det ses som att denna tid brer ut sig på bredden snarare än på längden.

Vi menar att kontrasteringen av de två olika situationerna visar ett handlande som ställer krav på lärare att kunna interagera med sina tidigare erfarenheter och samtidigt vara medveten om att erfarenheterna eventuellt inte är giltiga i den digitala situationen. Därför uppstår också krav på lärares förmåga att göra sig fria ifrån dessa och omfamna ett icke-vetande för att på så sätt kunna inta en mer utforskande hållning. I detta uppstår paradoxen att förberedelser som digital organisation och instruktioner behöver utföras med exakthet och precision. 


\title{
Att verka i statisk position med “(o)bekväm” tillgänglighet
}

I de avslutande exemplen beskriver Nina (excerpt 3a) respektive Liselott (excerpt 3b) sina handlingar och reflektioner vid själva genomförandet av undervisning:

\begin{abstract}
3a. Jag sitter framför datorn. Min kamera är på och jag lider lite i tysthet, eftersom man inte blir jättesnygg i kameran men ändå måste föregå med gott exempel. Eleverna vill ha lite mer information kring hur de ska skriva sina litteraturanalyser. De har fått skicka in frågor innan och jag har samlat ihop dem och gjort en genomgång. Jag börjar med att förklara inledningen. [...]Jag håller en monolog ut i ingenstans, känns det som. [...] Det stora flertalet av eleverna har nu sina kameror och mikrofoner avstängda. Jag pratar och förklarar ut i en stor tystnad. Jag känner mig nästan lite osäker, eftersom jag är van vid respons och interaktion under genomgångarna. Jag presenterar ett dokument på skärmen. Frågar om de ser. Tystnad. Sedan känner sig en ny elev tvungen att säga något: "Jag ser i alla fall.” Så plingar det till. Ytterligare en elev har anslutit. Jag hälsar eleven välkommen och pratar sedan på utifrån dokumentet, som visar hur man kan inleda en text. [...] Efter genomgången jobbar eleverna enskilt. Jag följer deras arbeten i delade dispositionsmallar i Classroom. 32 elever måste hinnas med under tiden som återstår, cirka 35 minuter. Samtidigt chattar elever med mig i den gemensamma tråden i Hangout, några mejlar, några ställer frågor i sina dispositionsmallar, och de frågorna kommer som mejl till mig, och andra skapar enskilda chattrådar med mig. Jag har helt klart fullt upp. När lektionen är slut får jag skriva att jag fortsätter svara på frågorna under dagen.
\end{abstract}

\begin{abstract}
3b. När det ser ut som att alla börjat jobba tar jag min första runda runt klassrummet, eftersom jag vet att en del elever inte säger till om de saknar något eller inte vet vad de ska göra. Jag försäkrar mig om att även dessa elever är igång och fortsätter vandra runt. Det blir många varv på en lektion. [...] Påbörjar en ny runda för att se så att allt löper på. Det gör det, så jag sätter mig på kanten av en bänk och läser ett par sidor i en av de böcker som eleverna läser. Tänker att den är riktigt bra. Tittar upp och ser att en elev sitter och stirrar ut i tomma intet. Går ner till honom och frågar om han kört fast. Ser att han börjat på den första uppgiften och ber honom berätta muntligt vad som hänt $\mathrm{i}$ den del av boken han just läst. Han förklarar kortfattat, men korrekt, och jag säger att det är just det han nyss sa som han ska skriva. Jag står kvar tills han skrivit klart och hjälper honom att komma igång med nästa uppgift. Inser att jag glömt att titta till eleven i Stillheten, så jag går dit och frågar hur det går. [...] Jag återvänder till klassrummet och går en ny vända runt. En elev passar på när jag är i närheten och frågar vad ett citat är. Jag förklarar och frågar om hon förstår hur jag menar, samtidigt som jag tittar på klockan och inser att det börjar vara dags att avsluta lektionen.
\end{abstract}

Utifrån dessa exempel beskriver vi "störningen" som den statiska, stillasittande positionen Nina måste inta framför skärmen för att befinna sig i det digitala undervisningsrummet under lektionstid. Den blir särskilt tydlig vid jämförelse med Liselotts "varande” i det fysiska klassrummet som karaktäriseras av en flexibel rörlighet med "många varv på en lektion". Lärarens fysiska position i klassrummet/ undervisningssituationen är central för hur yrket kan utövas, något som diskuterats inte minst avseende traditionell katederundervisning jämfört med s k “icke-traditionell” undervisning i kommunikativt samspel mellan två parter.

Lärarens statiska position framför datorn i distansläget skulle i viss mån kunna liknas vid en mer traditionell "katedergenomgång” framför klassen, där eleverna lyssnar och läraren pratar. 
Nina ger dock också uttryck för att hennes kropp är mer fysiskt exponerad i denna position. Kameran i kombination med lärarrollen gör att Ninas in-zoomade ansikte är i allas - också hennes eget - blickfång. Läraren beskriver i relation till detta ett "tyst lidande" som också relateras till att hon själv inte har samma tillgång till elevernas kroppar, ansiktsuttryck eller röster. En känsla av att hålla "en monolog rakt ut i ingenstans” skapar osäkerhet. Samtidigt är detta inget som Nina beskriver att hon justerar i aktiva handlingar som genom att exempelvis be eleverna att slå på sina kameror och mikrofoner. Avsaknaden av ömsesidighet $\mathrm{i}$ interaktionen blir dock påträngande, inte bara för läraren utan också för eleverna, i alla fall någon av dem, som verkar känna sig tvungen att ge läraren någon form av svar på frågan om de ser, som hänger i luften.

Liselott får genom sina "rundor" i det fysiska klassrummet helt andra förutsättningar att agera i relation till elevers eventuella uttryck för att inte ha förstått, eller som i fallet med en elevs tomma blick i excerpt 3b, som kan indikera tappat fokus, koncentration eller kanske motivation. Lika viktigt och fundamentalt i hur lektionen fortgår är att hon flertalet gånger kan konstatera att det mesta verkar "löpa på” och att hon alltså inte behöver ingripa. Detta konstaterande bygger på samma sinnliga samspel som möjliggörs av att elever och lärare befinner sig i samma fysiska klassrum. Det skapar också ett utrymme i både tid och rum för Liselott att i lugn och ro kontemplera, under lektionen, en del av det som utgör undervisningens objekt, nämligen den litteratur som eleverna läser.

Samtidigt visar Ninas beskrivning i 3a på hur interaktionen med eleverna, också under själva lektionen tar sig skriftspråkliga uttryck, vilket också kan ses som en anpassning till den statiska position hon befinner sig i framför skärm och tangentbord. Läraren beskriver ett intensivt, verbalt skriftspråkligt kommunicerande med eleverna, där hon också kan följa elevernas skrivprocess i realtid. Liksom i excerpt 2a, är det många elever som ställer frågor. I Liselotts fysiska klassrum, beskriver hon att ett fåtal frågor ställs och att eleverna passar på när hon är i närheten. Att färre frågor ställs när hon inte är i närheten, betyder inte per automatik att inga frågor uppstår hos eleverna. Det finns olika möjliga tolkningar av de många - skriftliga - frågorna i Ninas digitaliserade undervisningssituation. De skulle kunna vara uttryck för att eleverna tvingas bli mer kontaktsökande och/eller självständiga och aktiva i sin egen lärprocess. De skulle också kunna vara ett uttryck för att eleverna blir benägna och känner sig bekväma med att ställa frågor i skrift, och kommunicera med läraren i forum där inte alla andra elever har insyn eller kan höra vad som sägs. Även om denna individualisering 
i sig kan ses som positiv, kan Ninas tillgänglighet i sin obegränsade, synkrona och asynkrona form också te sig något “obekväm”. Detta då frågor som ställts i skrift läggs på hög och ställer krav på enskilda svar som hon får svårt att hinna med inom den tidsram som finns för en vanlig lektion. Den rumsliga inramningen är som redan konstaterats mer diffus. Ninas beslut att “fortsätta svara på frågorna under dagen” är ett uttryck för den relation av empati och responsivitet med vilken hon fortsatt konstruerar sin undervisning. Samtidigt är det en justering som i praktiken innebär att lektionen inte alls tar slut utan också får andra tidsmässiga dimensioner.

\section{Diskussion}

Frågan är vad våren 2020 kan lära oss om lärares (digitala) kompetens. För att besvara frågan har vi omfamnat den pandemiska händelsen, i termer av skolans omställning av undervisning som en kronologisk händelse, med ett före och ett efter med krav på kunnande och reflektion i direkt handling i den uppkomna pågående situationen.

Jämfört med de kända relationella situationer som utgjorde skolans undervisning före pandemin visar analysen på ett övergripande plan att de störningar som uppstår i "extremt digitaliserade omständigheter", dels handlar om ett upplösande av skolans traditionella rumslighet, dels om annorlunda kommunikativa praktiker. De digitala lösningarna "stör" den kroppsliga och materiella inramningen av undervisningen vilket framförallt påverkar de sinnliga verktyg, med vilka lärare vanligtvis agerar och kommunicerar då dessa delvis förskjuts och/eller "stympas". Överblick av och kontakt med elever begränsas av den mer statiska position som lärare placeras i av de digitala verktygen. Det krockar, som också Zhou, et al, (2020) visat, med lärares behov av spontan anpassning och flexibilitet i undervisningen. Lärare försöker dock genom samtidig reflektion genomföra upprepade, nödvändiga justeringar av sitt handlande. Främst manifesteras dessa i termer av 1) en verbal/röstburen organisering av undervisningen med en orientering mot tidslighet/klockslag 2) försök till uppskattning av elevers arbetsprocesser genom förutbestämd precisering av arbetet och dess omfattning liksom exakthet i förberedelser och digital rumslig organisation 3) en kompenserande kommunikativ sinnlighet och lyhördhet där responsivitet framstår som avgörande i det digitala undervisningslandskapet. Den ökade exaktheten och preciseringen av undervisningen liksom den kompenserande sinnligheten kan ses som konturer av ett alternativt strukturerande av undervisningens tid och rum. Dessa strukturella, många gånger 
skriftspråkliga uttryck, utmanar lärares organisatoriska, tidsmässiga begränsningar.

Sammantaget, i de digitala undervisningssituationer, där lärare, elever och teknik samspelar har nya, osäkra, utmanande och delvis paradoxala och obekväma digitala undervisningsrelationer uppstått. Lärare behöver härmed omfamna inte bara ett handlande genom kunnande utan också genom icke-vetande för att de ska klara att agera i ett digitalt “terra inkognita”. Sådan förmåga kan leda till upptäckter av möjligt pedagogiskt agerande i det, som beskrivs av Haj-Bolouri \& Flensburg (2017) som digitalt överskridande kontexter.

De förändringar av lärares villkor som uppstår i samband med omställningen av skolan, vilka konstaterats av denna studie kommer naturligtvis långsamt att försvinna genom en gradvis normalisering och anpassning till en ny verklighet. Egentligen finns det ingen tidpunkt för när detta sker, utan det handlar mer om hur skolan kommer att införliva följderna. Det mest intressanta är vilka förändringar som kan och ska accepteras i den nya normaliteten jämfört med den tidigare. Uppenbart är, när lärares kompetenser sätts på prov i distansundervisning, så framstår något annat än vad som tidigare oftast beskrivits ingå i lärares digitala kompetens, att rationellt kunna hantera, välja och vilja applicera olika digitala verktyg i undervisningen. Istället visar denna studie att lärares förmåga till responsivitet i situationsbundna relationer tillsammans med anpassningsförmåga och självtillit är avgörande kompetenser i den digitala undervisningen. Vi vill beskriva detta som reflexiv "kvalitativ digital kompetens" där det subjektiva, det känslomässiga och relationella framstår som mest väsentligt i lärares digitala yrkeskunnande. Detta tvingar oss, i relation till frågan vad vi ska vi ta med oss till efteråt, att rikta blicken mot en förståelse för, att skolans digitalisering också behöver fungera med intellectus. Detta är annorlunda jämfört med tidigare, då denna aspekt trängts undan av ett fokus på manualisering, systematisering och rationalisering av digital undervisningen där ratio fått dominera relativt ostört. Denna studie visar att det sinnliga, responsiva och osäkra också kräver utrymme, eventuellt på bekostnad av det organiserade, mätbara och det som vid första anblicken eventuellt kan verka mycket pålitligare (jmfr med Bornemark 2018). Att låta intellectus ta mer plats kan bidra till en förändrad syn på skolan och dess kunskapsutvecklande roll i samhället.

Skolans eventuellt fortsatta omställning efter pandemin, kommer förvaltas genom vårt sätt att (re)agera med dessa lärdomar. Av vikt är då att inte dra för snabba slutsatser utan att öppna upp för fortsatt reflektion och ett klokt justerande. Studien är förvisso begränsad, men den bidrar till att mätta delar av det oavvisliga behov av jämförelser, sammanhang och mening 
som uppstår ur varje kris. Ingen vet hur de "nya normala" pedagogiska praktikerna ser ut efter pandemin. Ingen har ett fulländat svar på detta, men det finns all anledning att ta vara på de små utsnitt av förståelser som lyfts fram av denna studie. De bidrar till den stora berättelsen och skapar förståelse för de kvalitativa digitala lärarkompetenser som i pandemins spår blivit synliga. Det handlar inte om att lämna skolans tidigare strukturer men det finns en möjlighet här och nu att ifrågasätta det invanda och lämna utrymme för det "nya". Det kan beskrivas som tillfälliga kvalitativa dimensioner av lärares (digitala) kompetenser, där lärare får tillåtelse och tid att arbeta öppet och utforskande. Det politiska, systematiserande fokus på mätbara resultat som funnits avseende olika insatser har tidigare tenderat att underskatta betydelsen av dessa mer svårdokumenterade, subjektiva, tillfälliga dimensioner av samma insatser (Lundström, 2018). När invanda former utmanas skapas inte omedelbart ett mervärde, eftersom upprätthållande strukturer ifrågasätts samtidigt som krav på andra ännu okända strukturer uppstår. Denna konflikt av osäkerhet och okontrollerbarhet skapar möjligheter för utveckling av relevanta kvalitativa (digitala) kompetenser. Frågan om tillit kommer att vara grundläggande för hur dessa kompetenser får utrymme i skolan i framtiden, de kommer inte att lättvindigt låta sig mätas.

\section{Referenser}

Anderson, T. \& Dron, J. (2014). Teaching Crowds: Learning and Social Media (Issues in Distance Education). Athabasca University.

Bergdahl, N. \& Nouri, J. (2020). Covid-19 och omställning till distansundervisning i svensk skola. Återföringsrapport, Stockholm. Hämtad den 5 maj, från https://www.ifous.se/app/uploads/2020/03/COVID19-omstllningen-till-distansundervisning.pdf

Bornemark, J. (2018). Det omätbaras renässans. En uppgörelse med pedanternas världsherravälde.

Denscombe, M. (2014). The Good Research Guide: For small-scale social research projects. Berkshire: Open University Press.

Deveraux, G. (1967). From Anxiety to Method in the Behavioural Sciences. The Hague: Mouton.

Fox, R. (2003). SARS epidemic: Teachers' experiences using ICTs. Education, 319-327.

Fox, R. (2007). ICT Use During SARS: Teachers' Experiences. Journal of Interactive Learning Research, 18(4). 
Fransson, G., Holmberg, J., Lindberg O.J. \& Olofsson A.D. (2019). Digitalise and capitalise? Teachers' self-understanding in 21st-century teaching contexts. Oxford Review of Education, 45(1), 102-118.

Gadamer, H. (1989). Förnuftet i vetenskapens tidsålder. Göteborg: Daidalos.

Gunawardena, C. N. (1995). Social presence theory and implications for interaction collaborative learning in computer conferences. International Journal of Educational Telecommunications. 1(2/3), 147-166.

Gunawardena, C. N., \& Zittle, F.J. (1997). Social presence as a predictor of satisfaction within a computer mediated conferencing environment. American Journal of Distance Education, 11(3), 8-26.

Haj-Bolouri, A. \& Flensburg, P. (2017). Conceptualizing the Essence of Presence in Distance Education through Digital Dasein. International Journal on E-Learning, 16(2), 149-173.

Kolb, D. (1984). Experiential Learning : experience as the source of learning and development. Englewood Cliffs, N.J: Prentice-Hall

Jankhe, A. \& Hirsh, Å., (2020). Varför förbättras inte elevresultaten trots alla insatser? Ifous rapportserie 2020:1, Stockholm.

Jones, L., Holmes, R., Macrae, C., \& Maclure, M. (2010). Documenting classroom life: how can I write about what I am seeing? Qualitative Research, 10(4), 479-491.

Lewin, K. (1997). Resolving social conflicts : Field theory in social science. Washington: American Psychological Association.

Lincoln, Y. S. (2001). Engagingng Sympathies: Relationships between Action Research and Social Constructivism. I Reason \& Bradbury (red) 2001, sid. 124 - 132. London: SAGE Publications INC.

Lundström, U. (2018). Lärares professionella autonomi under New Public Managementepoken Utbildning och Demokrati, 27(1), 33-59.

MacLure, M. (2013). The Wonder of Data. Cultural Studies - Critical Methodologies, 13(4), $228-232$.

Nilsson, S. (2012). Supporting participation in online learning communities with awareness information. International Journal of Web Based Communities, 8(4), 537 - 549.

Player-Koro, C., Bergviken Rensfeldt A., \& Selwyn, N. (2018) Selling tech to teachers: education trade shows as policy events, Journal of Education Policy, 33(5), 682-703. 
Reason, P. \& Bradbury, H. (2001). Conclusion: Broadening the Bandwith of Validity: Issues and Choice-points for Improving the Quality of Action Research. I Reason \& Bradbury (red) 2001, sid. 447-456. London: SAGE Publications.

Rourke, L., Anderson, T., Garrison, D. R., \& Archer, W. (2001). Assessing social presence in asynchronous, text-based computer conferencing. Journal of Distance Education, 14(3), $51-70$.

Russo, T., \& Benson, S. (2005). Learning with Invisible Others: Perceptions of Online Presence and their Relationship to Cognitive and Affective Learning. Journal of Educational Technology \& Society, 8(1), 54-62.

Sazmand Asfaranjan, Y., Shirzad, F., Baradari, F., Salimi, M., \& Salehi, M. (2013). Alleviating the Senses of Isolation and Alienation in the Virtual World: Socialization in Distance Education. Procedia - Social and Behavioral Sciences. 93, 332-337.

Selwyn, N., Nemorin, S., Bulfin, S. \& Johnson, N. F. (2017). Left to their own devices: the everyday realities of one-to-one classrooms, Oxford Review of Education, 43(3), 289310.

Schön, D.A. (2003). The reflective practitioner: how professionals think in action. Aldershot: Arena.

So, H.J., \& Brush, T.A. (2008). Student perceptions of collaborative learning, social presence and satisfaction in a blended learning environment: Relationships and critical factors. Computers \& Education, 51(1), 318-336.

Tabor, S. W. (2007). Narrowing the Distance: Implementing a Hybrid Learning Model for Information Security Education. Quarterly Review of Distance Education, 8(1), 47-57.

Touboulic, A., \& Walker, H. (2015). A relational, transformative and engaged approach to sustainable supply chain management: The potential of action research. Human Relations, $1-43$.

Tu, C., \& McIssac, M. (2002). The relationship of social presence and interaction in online classes. American Journal of Distance Education, 16(3), 131-150.

Utbildningsutskottet. (2015). Digitaliseringen i skolan - dess påverkan på kvalitet, likvärdighet och resultat i utbildningen. (2015/16:RFR18). Stockholm:

Riksdagstryckeriet. Hämtad den 26 maj, 2020 från https://data.riksdagen.se/fil/24B422586038-470F-80C6-F5CE149F401B 